\title{
Analysis of Leading Commodities in the North Barito District, Central Kalimantan Province
}

\author{
Ary Sudarta*, Andi Tenri Sompa, Muhammad Riduansyah Syafari
}

Masters in Development Administration, Postgraduate Program, Lambung Mangkurat University, Banjarmasin, Indonesia

DOI: $10.36348 /$ sjef.2021.v05i02.006 $\quad$ | Received: 10.02.2021 | Accepted: 22.02.2021 | Published: 26.02 .2021

*Corresponding author: Ary Sudarta

\section{Abstract}

This study aims to determine the superior commodity of plantation crops in the agricultural, forestry and fishery business fields as well as to what extent the ratio of income per capita of North Barito Regency and income per capita of superior sector farmers of plantation crops in North Barito Regency, Central Kalimantan Province. This research uses secondary data analysis method with literature study. Secondary data is in the form of production data, the number of household heads who have tried on plantation crop commodities and other supporting data in the last five years. The data analysis technique used in this research is Location Quotient (LQ) analysis as well as analysis of plantation crop farmers' per capita income and analysis of income per capita in North Barito Regency. Based on the results of the study showed that the superior plantation crops based on production were rubber, coffee, areca nut, cocoa, and candlenut. Meanwhile, based on the planted area, namely rubber, areca nut, cocoa, and candlenut. Based on the comparison of plantation crop farmers 'income per capita to PDRB per capita in North Barito Regency, there is a huge imbalance, farmers' per capita income is lower than PDRB per capita. This shows that the welfare of farmers is very low.

Keyword: Analysis; commodity

Copyright (C) 2021 The Author(s): This is an open-access article distributed under the terms of the Creative Commons Attribution 4.0 International License (CC BY-NC 4.0) which permits unrestricted use, distribution, and reproduction in any medium for non-commercial use provided the original author and source are credited.

\section{INTRODUCTION}

Development is a change towards a better condition through planned efforts. Regional economic development is a process in which local governments and community groups manage existing resources and form a partnership pattern between local governments and the private sector to create new jobs and stimulate the development of economic activity in the region [1]. The main objective of development is to improve people's welfare.

The economic structure of North Barito Regency for the last 5 (five) years has been largely supported by five business fields, including mining and quarrying; Agriculture, Forestry and Fisheries; Processing industry; Wholesale and Retail Trade, Repair of Automobiles and Motorcycles; as well as Transportation and Warehousing. Based on PDRB at constant prices in 2015 the agricultural, forestry, and fisheries business fields contributed to the PDRB of North Barito Regency by $12.43 \%$. Rubber plants rank first among plantation commodities in North Barito Regency. Likewise, the number of people who work on rubber commodities also occupies the largest position, around $85.68 \%$ of people. This shows that rubber is a mainstay commodity for people to support their economy and the regional economy.

The development of rubber plants based on the planted area, production, and the number of farmers who cultivate them really needs to be encouraged. However, if you look at the selling price of commodities, the average price of pepper, cocoa, and coffee per kilogram is much higher and relatively stable compared to rubber prices. The stable price of pepper, cocoa, and coffee is a good prospect for the community and local government to develop these crops. Based on the description, it is deemed necessary to know the advantages of each plantation crop as supporting the economy of the people of North Barito Regency and as the biggest contributor to PDRB in agriculture, forestry, and fisheries business fields. In this study, it is also necessary to determine the income of rubber farmers because $85.68 \%$ of family heads who do business in agriculture, forestry, and fisheries in North Barito Regency depend on the economy of rubber crops.

One way to determine the leading commodities in the district is through the calculation of Location 
Quotient Analysis (LQ). According to Hood [2] Location Quotient (LQ) theory is a simple economic development theory with all its advantages and limitations. The LQ technique is one of the approaches commonly used in basic economic models as a first step to understanding the sectors of activity that are driving growth [3]. Location Quotient analysis (LQ) is an analytical tool that seeks to measure the concentration of activity (industry) in an area by comparing its role in the regional economy with the role of similar activities or industries in the regional or national economy [1]. Developing the regional economy with the aim of prospering the people of North Barito Regency is very important so that research is needed on superior commodities that support the regional economy. Therefore, researchers are interested in conducting research with the title "Analysis of superior commodities in North Barito Regency, Central Kalimantan Province in 2020".

\section{METODE PENELITIAN}

This research uses a secondary data analysis method with the literature study. Secondary data is in the form of production data, the number of family heads who have tried on plantation crop commodities, and other supporting data in the last five years. The data was obtained from BPS North Barito Regency. The secondary data that has been obtained is then tabulated and analyzed according to the research objectives. Main commodities of plantation crops in the agricultural, forestry, and fishery business fields in North Barito Regency, Central Kalimantan Province as the first objective in the study are known by conducting a Location Quotient (LQ) analysis with the following formula:

$$
\mathrm{LQ}=\frac{\mathrm{Si} / \mathrm{Ni}}{\mathrm{S} / \mathrm{N}} \operatorname{atan} \frac{\mathrm{Si} / \mathrm{S}}{\mathrm{Ni} / \mathrm{N}}
$$

Informations:

Si: Total production of the commodity (i) from the plantation sub-sector in North Barito Regency

S: Total production of the commodity (i) from the plantation sub-sector in Central Kalimantan Province

$\mathrm{Ni}$ : Total production in the plantation sub-sector in North Barito Regency

$\mathrm{N}$ : Total production of the plantation sub-sector in Central Kalimantan Province

The implications of calculating Location Quotient (LQ) can be seen in Table 1 as follows:

Table-1: Implications of Location Quotient (LQ)

\begin{tabular}{|l|l|l|}
\hline No & LQ & Information \\
\hline 1 & LQ $>1$ & basic industries / commodities \\
\hline 2 & LQ $<1$ & not a basic industry / commodity \\
\hline 3 & LQ = 1 & able to meet the needs of their own region. \\
\hline
\end{tabular}

Then to find out how much the comparison of the income per capita of North Barito Regency and the income per capita of the farmers in the leading plantation sector in North Barito Regency, Central Kalimantan Province as the second objective in this study was to analyze the per capita income of the plantation plant farmers and the analysis of the per capita income of North Barito Regency. One indicator to measure the welfare of farmers is their income from these superior commodities.

\section{RESEARCH RESULTS AND DISCUSSION}

The following table shows the results of LQ calculations based on the production of plantation crops in North Barito Regency in 2015 - 2019 as follows:

Table-2: Results of LQ Analysis by Production in 2015-2019

\begin{tabular}{|l|l|l|l|l|l|l|}
\hline \multirow{2}{*}{ No } & Plantation crops & \multicolumn{6}{l}{ Location Quotient (LQ) } \\
\cline { 3 - 7 } & & $\mathbf{2 0 1 5}$ & $\mathbf{2 0 1 6}$ & $\mathbf{2 0 1 7}$ & $\mathbf{2 0 1 8}$ & $\mathbf{2 0 1 9}$ \\
\hline 1 & Rubber & 26,19 & 21,12 & 32,05 & 30,10 & 17,03 \\
\hline 2 & Coffee & 2,70 & 2,21 & 2,20 & 1,94 & 0,74 \\
\hline 3 & Clove & - & - & - & - & - \\
\hline 4 & Pepper & 0,17 & 0,19 & 2,14 & 0,00 & 0,13 \\
\hline 5 & Coconut & 2,80 & 2,16 & 1,17 & 0,69 & 0,57 \\
\hline 6 & Betel nut & 18,99 & 15,50 & 11,60 & 5,44 & 16,70 \\
\hline 7 & Cashew & 0,00 & 0,00 & 0,00 & 0,00 & 0,00 \\
\hline 8 & Cocoa & 550,60 & 169,07 & 143,93 & 134,11 & 67,65 \\
\hline 9 & Palm oil & 0,33 & 0,33 & 0,03 & 0,03 & 0,48 \\
\hline 10 & Candlenut & 4,36 & 7,39 & 30,78 & 24,01 & 26,42 \\
\hline
\end{tabular}

The results of the LQ calculation based on production can be seen in Table 2 which shows that rubber, coffee, areca nut, cocoa, and candlenut give an index score greater than one. Thus it can be concluded 
that rubber, coffee, areca nut, cocoa, and candlenut are the basic sectors in the economy of the North Barito Regency. Even though in 2019 coffee was no longer a base sector due to a decline in production. This also shows that the basic crop commodities with an LQ value of more than 1 (one) have characteristics that are able to attract a certain amount of income from outside the region to the community through export activities, so as to provide increased turnover and the value of the consumption cycle which will ultimately improve the regional economy.

Table-3: Results of LQ Analysis based on Planted Area in 2015-2019

\begin{tabular}{|l|l|l|l|l|l|l|}
\hline \multirow{2}{*}{ No } & \multirow{2}{*}{$\begin{array}{l}\text { Plantation } \\
\text { crops }\end{array}$} & Location Quotient (LQ) \\
\cline { 3 - 7 } & $\mathbf{2 0 1 5}$ & $\mathbf{2 0 1 6}$ & $\mathbf{2 0 1 7}$ & $\mathbf{2 0 1 8}$ & $\mathbf{2 0 1 9}$ \\
\hline 1 & Rubber & 3,69 & 4,03 & 4,03 & 4,09 & 4,12 \\
\hline 2 & Coffee & 0,44 & 0,19 & 0,17 & 0,38 & 0,32 \\
\hline 3 & Clove & 3,2 & - & - & - & - \\
\hline 4 & Pepper & 0,11 & 0,29 & 0,29 & 0,29 & 0,29 \\
\hline 5 & Coconut & 1,28 & 0,21 & 0,20 & 0,25 & 0,25 \\
\hline 6 & Betel nut & 7,28 & 3,07 & 3,79 & 11,33 & 11,27 \\
\hline 7 & Cashew & 0,07 & 0,00 & 0,00 & 0,00 & 0,00 \\
\hline 8 & Cocoa & 27,44 & 33,19 & 31,52 & 28,43 & 28,71 \\
\hline 9 & Palm oil & 0,07 & 0,06 & 0,07 & 0,07 & 0,07 \\
\hline 10 & Candlenut & 15,67 & 7,66 & 7,70 & 7,72 & 10,37 \\
\hline
\end{tabular}

Based on Table 3, we can observe that more than one LQ value is found in rubber, areca nut, cocoa, and candlenut. This shows that the plantation crop is a base sector or base commodity. The LQ value of plantation crops have fluctuated which tends to be unstable from year to year. This is due to the difference in the production of plantation crops that is too far in each district in Central Kalimantan Province. Knowledge of the comparative advantage of a region can be used by policymakers to encourage changes in the structure of the regional economy towards commodities with comparative advantages. If commodities that have a comparative advantage for a region are known in advance, commodity-based development can be hastened without waiting for pressure from market mechanisms that often run slowly.

The calculation of plantation farmer income per capita is obtained from the production of each commodity each year multiplied by the average retail price per year then divided by the number of farmers who own plantation crops. The comparison of farmers' income per capita and GDP per capita in 2015 to 2019 can be seen in Table 4 as follows:

Table-4: Comparison of Farmers' Income Per Capita and PDRB per capita in 2015-2019

\begin{tabular}{|c|c|c|c|c|c|c|c|c|c|c|c|}
\hline \multirow[t]{2}{*}{ No } & \multirow[b]{2}{*}{ 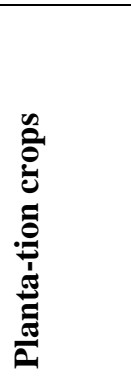 } & \multicolumn{2}{|l|}{2015} & \multicolumn{2}{|l|}{2016} & \multicolumn{2}{|l|}{2017} & \multicolumn{2}{|l|}{2018} & \multicolumn{2}{|l|}{2019} \\
\hline & & 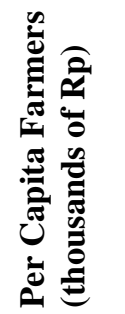 & 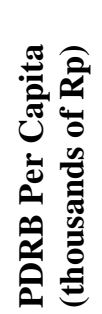 & 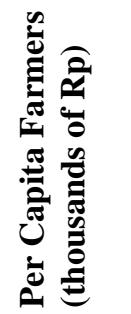 & 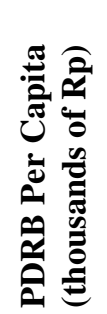 & 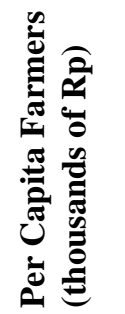 & 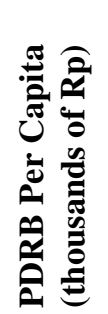 & 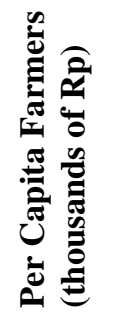 & 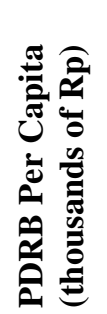 & 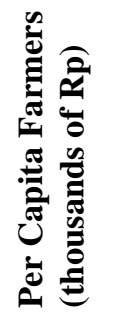 & 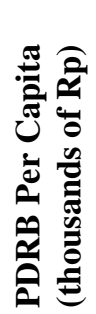 \\
\hline 1 & Rubber & $6.497,68$ & 52.621 & $5.418,67$ & 57.312 & $7.296,76$ & 63.849 & $9.771,15$ & 70.918 & $\begin{array}{l}14.321,9 \\
5\end{array}$ & 74.979 \\
\hline 2 & Coffee & 308,80 & 52.621 & $1.109,50$ & 57.312 & $2.037,00$ & 63.849 & 1.904 & 70.918 & 1.386 & 74.979 \\
\hline 3 & Clove & 0 & 52.621 & 0 & 57.312 & 0 & 63.849 & 0 & 70.918 & 0 & 74.979 \\
\hline 4 & Pepper & $8.426,67$ & 52.621 & 960 & 57.312 & 15.600 & 63.849 & 0 & 70.918 & 877,42 & 74.979 \\
\hline 5 & Coconut & 792,28 & 52.621 & 650,80 & 57.312 & 540,41 & 63.849 & 285,71 & 70.918 & 985,14 & 74.979 \\
\hline 6 & Betel nut & 0 & 52.621 & 0 & 57.312 & 0 & 63.849 & 0 & 70.918 & 0 & 74.979 \\
\hline 7 & Cashew & 0 & 52.621 & 0 & 57.312 & 0 & 63.849 & 0 & 70.918 & 0 & 74.979 \\
\hline 8 & Cocoa & $\begin{array}{l}14.643,7 \\
5\end{array}$ & 52.621 & $\begin{array}{l}10.290,7 \\
0\end{array}$ & 57.312 & $\begin{array}{l}41.860,0 \\
0\end{array}$ & 63.849 & $\begin{array}{l}41.910,4 \\
5\end{array}$ & 70.918 & $\begin{array}{l}31.570,6 \\
5\end{array}$ & 74.979 \\
\hline 9 & Palm oil & $8.065,17$ & 52.621 & $7.714,02$ & 57.312 & $1.101,90$ & 63.849 & 801,37 & 70.918 & $\begin{array}{l}41.906,3 \\
2\end{array}$ & 74.979 \\
\hline 10 & $\begin{array}{l}\text { Candlenu } \\
\mathrm{t}\end{array}$ & 0 & 52.621 & 0 & 57.312 & 0 & 63.849 & 0 & 70.918 & 0 & 74.979 \\
\hline
\end{tabular}

Source: data processing results 
Based on the comparison of the per capita income of the plantation plant farmers to the GDP per capita each year, there is a considerable income gap between the income of the farmers and the GDP per capita. The increase and decrease in per capita income of rubber plant farmers are influenced by fluctuating production and retail prices at the farm level. PDRB per capita of North Barito Regency has increased every year because it is influenced by the increase in the contribution of mining and excavation business fields every year this is due to the increase in the price of coal commodity. The low income per capita of farmers shows the level of farmer welfare is also low. Overall, the per capita income of plantation plant farmers, both in the basic and non-basic sectors, is very low compared to the PDRB per capita of North Barito Regency in 2015-2019.

\section{CONCLUSSION}

Based on the research results, it can be concluded that the superior plantation crops according to the calculation of LQ $>1$ based on production are rubber, coffee, areca nut, cocoa, and candlenut. The leading plantation crops according to the calculation of LQ > 1 based on the planted area are rubber, areca nut, cocoa, and candlenut. Meanwhile, based on the comparison of plantation crop farmers' income per capita to PDRB per capita in North Barito Regency, there is a very large imbalance. The income per capita of farmers is much lower than the PDRB per capita. This shows that the welfare of farmers is still very low.

\section{REFERENCES}

1. Arsyad, L. (1999). Ekonomi Pembangunan, Edisi Keempat, STIE YKPN, Yogyakarta.

2. Ron, H. (1998). Economic Analysis: A Location Quotient. Primer Principal Sun Region Associates, Inc.

3. Hendayana, R. (2003). Aplikasi Metode Location Quotient (LQ) Dalam Penentuan Komoditas Unggulan Nasional. Balai Pengkajian dan Pengembangan Teknologi Pertanian, Bogor. 